Penelitian

\title{
Penilaian Fungsi dan Dinamika Kerja Jantung melalui Ekokardiografi terhadap Pengaruh Kombinasi Anestesia Umum pada Babi Domestik (Sus domesticus)
}

\section{Assessment of the Heart's Function and Dynamics through Echocardiography on the Combination Effects of the General Anesthesia in Domestic Pigs (Sus Domesticus)}

\author{
Arni Diana Fitri' ${ }^{{ }^{*}}$, Deni Noviana ${ }^{2}$, Gunanti $^{3}$, Agik Suprayogi ${ }^{4}$ \\ ${ }^{1}$ Program Studi IImu Biomedis Hewan (IBH) IPB \\ ${ }^{2}$ Departemen Klinik Reproduksi dan Patologi, FKH IPB \\ ${ }^{3}$ Departemen Klinik, Reproduksi, dan Patologi, FKH IPB \\ ${ }^{4}$ Departemen Anatomi, Fisiologi, dan Farmakologi, FKH IPB \\ *Penulis untuk korespondensi: arnidianafitri@gmail.com \\ Diterima 16 Juli 2020, Disetujui 26 Oktober 2020
}

\begin{abstract}
ABSTRAK
Protokol perawatan kardiovaskular yang baru diusulkan harus diuji pada hewan laboratorium, sebelum diterapkan oleh obat manusia. Untuk tujuan ini, hewan laboratorium yang banyak digunakan adalah babi. Menggunakan babi dalam penelitian ini seringkali memerlukan prosedur anestesi. Alat diagnostik yang paling banyak digunakan untuk kardiovaskular adalah ultrasonografi jantung atau ekokardiografi. Ekokardiografi dapat digunakan untuk mengevaluasi aliran volume darah dan kemampuan kontraksi jantung dengan perhitungan ekokardiografi. Penelitian ini bertujuan untuk mengevaluasi pemberian kombinasi injeksi anestesi umum untuk fungsi dan dinamika jantung babi dengan menggunakan ekokardiografi. Pengamatan meliputi detak jantung(kali/menit), curah jantung (L/mnt), volume stroke ( $\mathrm{ml} / \mathrm{mnt}$ ), fraksi ejeksi (\%), dan pemendekan fraksional (\%). Dalam penelitian ini, digunakan 9 babi jantan dan betina, usia 3-4 bulan dengan berat $25-30 \mathrm{~kg}$, dibagi menjadi 3 kelompok kombinasi anestesi (ketamin dan acepromazine (KA); ketamin dan medetomidine (KM); tiletamine-zolazepam dan xylazine(ZX)). Hasil penelitian menunjukkan bahwa tidak satu pun dari tiga kelompok anestesi menunjukkan perbedaan yang signifikan dalam kinerja jantung. Kombinasi anestesi ZX paling baik diterapkan untuk operasi jantung babi karena kombinasi anestesi ini menghasilkan frekuensi denyut jantung yang stabil dan rendah dibandingkan dengan kelompok KA dan KM tetapi masih m enunjukkan volume stroke yang tinggi, curah jantung, fraksi ejeksi dan nilai sortasi fraksional.
\end{abstract}

Kata kunci: anastesi babi, ekokardiografi, curah jantung, stroke volume, fractional shortening, ejection fraction

\begin{abstract}
A newly proposed cardiovascular treatment protocol must be tested on laboratory animals, before being applied by human medicine. For this purpose, laboratory animals that are widely used are pigs. Using pigs in this research oftentimes requires anesthesia procedures.The most widely used diagnostic tool for cardiovascular is cardiac ultrasonography or echocardiography. Echocardiography can be used to evaluate the flow of blood volume and the ability of heart contractions by echocardiographic calculations. This study aims to evaluate the administration of general anesthetic injection combination to the pig's heart function and dynamics by using echocardiography. Observations included heart rate (times / $\mathrm{min})$, cardiac output ( $\mathrm{L} / \mathrm{min})$, stroke volume $(\mathrm{ml} / \mathrm{min})$, ejection fraction (\%), and fract ional shortening (\%). In this study, used 9 male and female pigs, age 3-4 months with 25-30 kg body weight, divided into 3 groups of anesthesia combination (ketamine and acepromazine (KA); ketamine and medetomidine (KM); tiletaminezolazepam and xylazine $(Z X))$. The results showed that none of the three anesthetic groups showed significant differences in cardiac performance. The combination of ZX anesthesia is best applied for swine cardiac surgery because this combination of anesthesia produces a low stable heart rate frequency compared to KA and KM groups but still shows high stroke volume, cardiac output, ejection fraction and fractional sortening values.
\end{abstract}

Keywords: swine anesthesia, echocardiography, cardiac output, stroke volume, fractional shortening, ejection fraction 


\section{PENDAHULUAN}

Tindakan pembiusan seringkali diperlukan pada babi yang dijadikan sebagai hewan model penelitian. Keberhasilan penelitian sangat ditentukan oleh metode dan pemilihan anestesia yang tepat (Gunanti et al., 2011). Beberapa jenis obat bius yang telah digunakan pada babi, diantaranya senyawa transquilizer, neuroleptik, anestesia disosiatif, barbiturat dan anestesia inhalasi sebagai agen tunggal maupun kombinasi, untuk kepentingan pembedahan (Flecknell, 2009).

Anestesia dapat mengakibatkan efek pada sistem kardiovaskular dan pernapasan seperti peningkatan kerja jantung, peningkatan konsumsi oksigen, takikardia, bradikardia, hipertensi, dan hipotensi (Kolh et al., 2004). Akata (2007), menyebutkan bahwa anestesia umum akan mengganggu stabilitas kardiovaskular dengan memengaruhi fungsi jantung dan reaktivitas vaskular yang secara signifikan dapat mengganggu distribusi curah jantung ke organ-organ.

Beberapa penelitian yang mengamati dampak anestesia pada sistem kardiovaskular khususnya jantung babi telah dilakukan dengan menggunakan radiografi, ekokardiografi (Lee et al., 2007), elektrokardiografi (Liu at al., 2012) dan MRI (magnetic resonance imaging) (Pop et al., 2013). Alat peneguh diagnostik yang paling banyak digunakan untuk penyakit kardiovaskular manusia dan hewan adalah radiografi, elektrokardiografi dan ultrasonografi jantung atau ekokardiografi. Ekokardiografi merupakan teknik diagnosis jantung dengan menggunakan gelombang suara ultra high-frequency yang dapat memberikan informasi morfologi jantung seperti struktur jantung yang meliputi ukuran dan ketebalan, pergerakan otot jantung dan katup, serta aliran darah di dalam pembuluh darah (Mohamed et al., 2010; Noviana et al., 2018).

Parameter yang dapat diukur dengan ekokardiografi adalah stroke volume (SV), cardiac output (CO), fractional shortening (FS), dan ejection fraction (EF) (Fontes-Sousa et al., 2006). Penelitian yang lebih spesifik tentang pengaruh kombinasi anestesia umum perinjeksi ketamine-acepromazine, ketaminemedetomidine dan tiletamine dan zolazepamxylazine terhadap fungsi dan dinamika kerja jantung babi belum banyak diketahui. Kombinasi agen anestesia tersebut dipilih karena agen anestesia tersebut mudah ditemukan, harga ekonomis serta tidak memerlukan banyak peralatan pendukung dalam pengaplikasiannya.

Tujuan utama dari penelitian ini adalah untuk mengevaluasi pemberian kombinasianestesia umum perinjeksi ketamine-acepromazine, ketamine- medetomidine, dan tiletamine dan zolazepam-xylazine terhadap fungsi dan dinamika kerja jantung babi melalui pengamatan ekokardiografi. Pengamatan meliputi laju detak jantung (kali/menit), cardiac output $(\mathrm{L} / \mathrm{menit})$, stroke volume ( $\mathrm{ml} / \mathrm{menit})$, ejection fraction (\%), dan factional shortening (\%).

Melalui penelitian ini diharapkan dapat memperoleh informasi dasar mengenai pengaruh pemberian anestesia umum perinjeksi ketamineacepromazine, ketamine-medetomidine dan tiletamine dan zolazepam-xylazine terhadap fungsi dan dinamika kerja jantung babi dengan menggunakan ekokardiografi.

\section{BAHAN DAN METODE}

\section{Waktu dan Tempat Penelitian}

Penelitian ini dilaksanakan antara bulan Desember 2019 hingga Januari 2020. Penelitian dilakukan di Laboratorium Penelitian Rumah Sakit Hewan Pendidikan Fakultas Kedokteran Hewan Institut Pertanian Bogor.

\section{Alat dan Bahan}

Alat yang digunakan dalam penelitian ini adalah mesin Ultrasonografi merek Chison tipe Q8 Color Doppler, meja USG, personal protection equipment (PPE), serta satu set laptop untuk pencatatan. Bahan yang digunakan untuk penelitian yaitu babi domestik (Sus domesticus) umur 3-4 bulan (Juvenile) dengan jenis kelamin jantan dan betina serta kisaran berat badan $25-30 \mathrm{~kg}$. Agen anestesia yang digunakan adalah ketamine HCL $10 \%$ (Ketamil ${ }^{\circledR}$, troy Laboratories PTY Limited, Australia), acepromazine maleat $1.5 \%$ inj (Castran ${ }^{\circledR}$ Metaalweg 85804 CG Venray the Netherlands), medetomidine $\mathrm{HCl} 0.1 \%$ (Medetor ${ }^{\circledR}$. Virbac animal Health, Caros-Prancis), tiletamine $\mathrm{HCL} 2.5 \%$ dan zolazepam HCL $2.5 \%$ (Zoletyl $50 \AA$, Virbac Animal Health, Caros-Prancis) dan xylazine $2 \%$ (Xyla ${ }^{\circledR}$, Interchemie, Holland), gel, serta alkohol $70 \%$.

\section{Prosedur Penelitian}

Penelitian ini telah mendapatkan persetujuan prosedur perlakuan (Ethical approval) dari Fakultas Kedokteran Hewan IPB University, nomor: 152/KEH/SKE/X/2019.

Penelitian diawali dengan tahap persiapan kandang karantina pada saat hewan baru datang di fasilitas penelitian dan aklimatisasi untuk menyamakan status kesehatan dan fisiologi hewan. 
Tahap selanjutnya yaitu tahap pengambilan data ekokardiografi masing-masing hewan dengan 3 jenis kombinasi anestesia. Tahapan terakhir adalah pemulihan sebelum hewan dipergunakan untuk tujuan berikutnya.

Hewan penelitian dibagi menjadi 3 kelompok perlakuan kombinasi anestesia umum yaitu kelompok KA, KM dan ZX (Tabel 1). Setelah hewan teranestesia hewan diposisikan di atas meja, selanjutnya dilakukan pemeriksaan jantung dengan menggunakan ekokardiografi. Pemeriksaan ekokardiografi dilakukan pada saat hewan berada pada tahap ketiga anestesia.

Parameter yang diamati selama penelitian adalah struktur jantung kiri dari ekokardiografi meliputi pengukuran left ventricular internal dimension diastole (LVIDd), left ventricular internal dimension systole (LVIDs), left ventricular free wall diastole (LVWd), left ventricular free wall systole (LVWs), interventricular septum diastole (IVSd), dan interventricular septum systole (IVSs). Penentuan volume aliran darah berdasarkan pengamatan stroke volume (SV) dan cardiac output (CO). Penentuan kekuatan kontraksi berdasarkan pengamatan ejection fraction (EF) dan fractional shortening (FS). (Penninck \& Andrea'd'Anjou, 2015).

\section{Hewan Penelitian}

Jumlah hewan yang digunakanadalah 9 ekor babi dengan tidak membedakan jenis kelamin. Penentuan jumlah ini didasarkan pada pengumpulan data deskriptif.

Kandang hewan dibuat bentuk panggung untuk individu. Kandang disiapkan dengan mengatur kelembaban $>80 \%$ dan suhu $18-26^{\circ} \mathrm{C}$. Photo periode kandang diatur 12 jam terang dan 12 jam gelap. Fasilitas hewan diperiksa dua kali sehari untuk melihat status kesehatan, makan dan minum (FASS, 2010).
Penelitian diawali dengan adaptasi hewan coba dengan menyamakan status kesehatan dan fisiologisnya. Masa aklimatisasi dilakukan selama $10 \mathrm{sam}$ pai 14 hari. Hewan masuk fasilitas penelitian dimandikan terlebih dahulu dan selama masa aklimatisasi hewan dimonitor keadaan umum, tingkah laku, nafsu makan, urinasi dan defekasi setiap harinya (Smith \& Swindle 2006). Hewan diberikan obat-obatan untuk mengeliminasi endoparasit dan ektoparasit ivermectin $300 \mu \mathrm{g} / \mathrm{kg}$ BB intra muscular (IM)/subcutaneous (SC). Kandang dan peralatan disanitasi terlebih dahulu dengan desinfektan (NRC, 2011).

\section{Pembiusan Parenteral}

Pembiusan dilakukan berdasarkan 3 kelompok kombinasi enestesia seperti yang disajikan pada Tabel 1. Data monitor pasien dan ekokardiografi diambil pada saat hewan telah mencapai tahap 3 anestesia. Hewan dipuasakan makan selama 12 jam dan minum selama 4 jam sebelum anestesia. Premedikasi atropine atau agen lain tidak digunakan dalam penelitian ini. Pembiusan diberikan secara intra muscular (IM) pada muskulus trapezius setelah babi dikekang secara fisik.

\section{Pengambilan Data}

Data penelitian didapat dari pemeriksaan parameter kinerja jantung dengan ekokardiografi dilakukan secara otomatis oleh sistem USG Chison Q8. Pemeriksaan ekokardiografi dilakukan dengan posisi rebah kanan/right parasternal (RPS), dengan posisi tranduser short axis views (SA). Tranduser diposisikan setelah detak jantung terpalpasi antara intercostae 4-6. Posisi tranduser short axis (SA) dilakukan untuk mendapatkan pencitraan $\mathrm{M}$-mode untuk pengukuran detak jantung, left ventricular internal dimention systole (LVIDs), left ventricular wall, diastole (LWWd), left ventricular wall systole (LVWs),

Tabel 1 Kelompok perlakuan kombinasi anestesia umum pada babi domestik

\begin{tabular}{llll}
\hline Kelompok & $\begin{array}{l}\text { Kombinasi obat } \\
\text { anesthesia }\end{array}$ & $\begin{array}{l}\text { Dosis } \\
\text { obat }\end{array}$ & $\begin{array}{l}\text { Rute } \\
\text { injeksi }\end{array}$ \\
\hline KA & ketamine + acepromazine & $22 \mathrm{mg} / \mathrm{kg}+1.1 \mathrm{mg} / \mathrm{kg}$ & $\mathrm{IM}$ \\
$\mathrm{KM}$ & ketamine + medetomidine & $10 \mathrm{mg} / \mathrm{kg} \mathrm{im}+0.08 \mathrm{mg} / \mathrm{kg}$ & $\mathrm{IM}$ \\
ZX & $\begin{array}{l}\text { Tiletamine dan zolazepam } \\
+ \text { xylazine }\end{array}$ & $2-7 \mathrm{mg} / \mathrm{kg}+0.2-1 \mathrm{mg} / \mathrm{kg}$ & $\mathrm{IM}$ \\
& & \\
\hline
\end{tabular}


inter ventricular septum, diastole (IVSd), inter ventricular septum, systole (IVSs), ejection fraction (EF), fraction shortening (FS), cardiac output (CO), dan stroke volume (SV).

Frekuensi detak jantung dihitung dengan mengukur antara dua puncak gelombang pada tampilan layar monitor ekokardiografi. Interventricular septum, dyastole (IVDSd) dihitung dengan mengukur jarak interventrikuler septa pada saat akhir diastol sedangkan IVDSs dihitung dengan mengukur jarak interventrikuler septa saat akhir sistol. Penghitungan LVIDd dilakukan pada saat akhir diastol sementara LVIDs diukur pada saat sistol. Left ventricular free wall (LVW) dihitung dengan mengukur dinding ventrikel kiri pada saat akhir diastol dan sistol (Penninck \& Andrea'd'Anjou, 2015). Data CO, SV, EF, dan FS diketahui melalui hasil penghitungan data pada mesin ultrasonografi (USG). Data gambar dipindahkan secara offline setelah prosedur. Rumus turunan CO, SV, EF, dan FS disajikan pada Tabel 2. Semua data diambil sebanyak 3 kali pengulangan.

\section{Rancangan Penelitian dan Analisi Data}

Data kualitatif yang diperoleh disajikan dalam bentuk deskriptif naratif, sedangkan data kuantitatif diuji secara statistika dengan menggunakan pengh itungan analysis of variance (ANOVA) one way. Sebelum dianalisis, data sudah dievaluasi asumsi di ANOVA dan sudah terpenuhi. Perhitungan analisis ini dilakukan karena skala data berupa rasio yang yang memiliki sebaran normal dan bertujuan untuk melihat perbedaan antara lebih dari dua populasi. Apabila terjadi perbedaan, data uji lanjut dengan Uji Jarak Berganda Duncan (UJBD)(Yitnosumarto1991). Signifikansi statistik did efinisikan sebagai $P<0.05$. Data dianalisis menggunakan piranti lunak SPSS for windows ${ }^{\circledR}$ dan Microsoft excel ${ }^{\circledR}$ (SPSS Inc).

\section{HASIL}

Pengamatan parameter pengukuran dinding dan ruang ventrikel kiri yang didapat dari ekokardiogram disajikan pada Tabel 3. Nilai IVSd kelompok KA lebih besar dibandingkan kelompok KM dan ZX. Nilai LVIDd kelompok ZX lebih besar dibandingkan kelompok KA dan KM. Nilai LVPWd kelompok ZX lebih besar dibandingkan kelompok KA dan KM. Nilai IVSs kelompok KA lebih besar dibandingkan kelompok KM dan ZX. Nilai LVIDs kelompok ZX lebih besar dibandingkan kelompok KA dan KM. Nilai LVPWs kelompok ZX lebih besar dibandingkan kelompok KA dan KM.

Hasil uji perhitungan kinerja jantung kelompok perlakuan anestesia dengan menggunakan ekokardiografi dapat dilihat pada Tabel 4. Rataan detak jantung paling tinggi terjadi pada kelompok perlakuan kombinasi anestesia KA dan yang paling rendah pada kelompok ZX. Nilai stroke volume paling tinggi terjadi pada kelompok perlakuan ZX dan yang paling rendah pada kelompok KA. Rataan tertinggi cardiac output (CO) terdapat pada kelompok KA, kemu dian diikuti kelompok ZX dengan nilai yang tidak jauh berbeda dilihat dari nilai standar deviasi kedua kelompok tersebut. Nilai CO terendah pada kelompok KM.

Rataan tertinggi ejection fraction terdapat pada kelompok ZX, kemudian diikuti kelompok KA. Nilai rataan EF terendah ada pada kelompok KM. Rataan persentase fractional shortening tertinggi terdapat pada kelompok KA, kemudian diikuti kelompok ZX dengan nilai yang tidak jauh berbeda dilihat dari nilai standar deviasi kedua kelompok tersebut. Persentase FS terendah ada pada kelompok KM.

Hasil analisis detak jantung pada ketiga kelompok perlakuan menunjukkan hasil yang berbeda nyata $(P<0.05)$. Data laju detak jantung dihitung kali permenit. Dari diagram (Gambar 1)

Tabel 2 Rumus turunan perhitungan ekokardiografi

\begin{tabular}{ll}
\hline \multicolumn{1}{c}{ Parameter } & \multicolumn{1}{c}{ Persamaan } \\
\hline Left ventricular end diastolic volume (LVEd) & {$[7 / 2.4+$ LVIDd ]x LVIDd } \\
Left ventricular end systolic volume (LVEs) & {$\left[7 / 2.4+\right.$ LVIDs ]x LVIDs ${ }^{3}$} \\
Stroke volume (SV) & LVEd-LVEs \\
Cardiac output (CO) & SV x HR \\
Ejection fraction (EF) & {$[$ LVED-LVES/ LVED] x 100 } \\
Fractional shortening (FS) & {$[$ LVIDd-LVIDs /LVIDd] x 100 } \\
\hline
\end{tabular}

LVIDd: left ventricular internal dimention saat diastol, LVIDs: left ventricular internal dimention saat sistol, HR: denyut jantung (Sumber: Boon, 2011) 
terlihat nilai detak jantung kelompok KA memiliki rataan paling tinggi, kemudian kelompok KM.

Perbandingan parameter stroke volume pada ketiga kelompok anestesia disajikan pada Gambar 1, terlihat bahwa kelompok ZX memiliki volume stroke volume (SV) paling tinggi, diikuti kelompok KM dan yang paling kecil volumenya pada kelompok KA.

Nilai cardiac output yang didapat dari perakuan kombinasi anestesia tersaji pada Gambar 1, dapat dilihat bahwa diagram kelompok perlakuan KA dan kelompok ZX menunjukkan rataan volume yang hampir sama dalam waktu satu menit. Perhitungan CO kelompok KM berada dibawah dua kelompok perlakuan lain. Analisis uji lanjut parameter ini tidak menunjukkan perbedaan signifikan pada ketiga kelompok perlakuan.

Nilai perhitungan diagram persentase ejection fraction (EF) disajikan dalam Gambar 1. Ejection fraction adalah indeks rasio dari volume ventrikular dengan perhitungan hasil dari selisih volume diastol akhir kontraksi dengan volume sistol akhir kontraksi (Penninck \& Andrea' d'Anjou, 2015). Nilai EF dihitung untuk melihat persentase darah yang dikeluarkan oleh ventrikel kiri untuk setiap kontraksi jantung. Ejection fractional digunakan sebagai dasar pengukuran efisiensi pemompaan jantung dan sebagai indikator tingkat kemampuan jantung berkontraksi (Boon, 2011). Berdasarkan nilai yang didapat dari tiga kelompok perlakuan anestesia, terlihat bahwa kelompok ZX memilik presentasi EF paling tinggi dan kemudian disusul kelompok KA. Persentase EF paling rendah pada kelompok KM. Penelitian saat ini tidak menunjukkan peningkatan yang jelas dalam fungsi kardiovaskular, ditunjukkan dengan hasil nilai $\mathrm{P}>0.05$, maka tidak terdapat perbedaan signifikan pada ketiga kelompok perlakuan.

Nilai FS dari kelompok penelitian kombinasi anestesia disajikan pada Gambar 1. Dari gambar dapat dilihat bahwa persentase fractional shortening (FS) paling tinggi pada kelompok KA tidak jauh berbeda dengan jumlah persentase kelompok ZX. Sementara nilai pada kelompok KM menunjukkan hasil FS paling rendah. Hasil ini berhubungan dengan parameter lainnya. Untuk masing-masing perlakuan kombinasi anestesia, memengaruhi kinerja jantung dan nilai FS.

\section{PEMBAHASAN}

Masing-masing agen anestesia yang diberikan memberikan pengaruh yang berbeda pada sistem kardiovaskular. Ketamine mendominasi kerja jantung sebagai kardiostimulator (Plumb, 2018). Ketamine jika dikombinasikan dengan medetomidine menunjukkan durasi muskulorelaksan lebih panjang dibanding kombinasi dengan agen anestesia lain (Sakaguchi et al., 1995; Plumb, 2018). Hal ini sesuai dengan hasil (Tabel 4) yaitu detak jantung kombinasi dengan ketamine lebih tinggi dibanding kelompok ZX. Data pengukuran dinding dan rongga ventrikel kiri hewan percobaan pada ketiga kelompok perlakuan, baik pada dinding ventrikel kiri, ruang dan batas antara ventrikel kiri dan ventrikel kanan tidak berbeda nyata $(P>0.05)$ pada ketiga kelompok perlakuan penelitian. Halini berarti pemberian kombinasi

Tabel 3 Data rata-rata \pm simpangan baku pengukuran dinding dan ruang ventrikel kiri babi domestik (Sus domesticus) dengan menggunakan ekokardiografi

\begin{tabular}{|c|c|c|c|c|c|c|c|c|c|c|}
\hline \multirow[b]{3}{*}{$\operatorname{IVSd}(\mathrm{cm})$} & \multicolumn{9}{|c|}{ Perlakuan } & \multirow{3}{*}{$\begin{array}{c}\text { P-value } \\
0.223\end{array}$} \\
\hline & \multicolumn{3}{|c|}{ KA } & \multicolumn{3}{|c|}{$K M$} & \multicolumn{3}{|c|}{$Z X$} & \\
\hline & 1.04 & \pm & $0.43^{\mathrm{a}}$ & 0.79 & \pm & $0.21^{\mathrm{a}}$ & 0.83 & \pm & $0.27^{a}$ & \\
\hline LVIDd (cm) & 2.63 & \pm & $0.53^{\mathrm{a}}$ & 2.86 & \pm & $0.87^{\mathrm{a}}$ & 3.05 & \pm & $0.17^{\mathrm{a}}$ & 0.340 \\
\hline LVPWd $(\mathrm{cm})$ & 0.10 & \pm & $0.44^{\mathrm{a}}$ & 0.83 & \pm & $0.22^{\mathrm{a}}$ & 0.96 & \pm & $0.15^{\mathrm{a}}$ & 0.472 \\
\hline IVSs (cm) & 1.26 & \pm & $0.30^{\mathrm{a}}$ & 1.03 & \pm & $0.23^{\mathrm{a}}$ & 1.12 & \pm & $0.16^{\mathrm{a}}$ & 0.125 \\
\hline LVIDs (cm) & 1.26 & \pm & $0.56^{\mathrm{a}}$ & 1.66 & \pm & $0.74^{\mathrm{a}}$ & 1.55 & \pm & $0.43^{\mathrm{a}}$ & 0.344 \\
\hline LVPWs (cm) & 1.32 & \pm & $0.25^{\mathrm{a}}$ & 1.24 & \pm & $0.41^{\mathrm{a}}$ & 1.46 & \pm & $0.39^{\mathrm{a}}$ & 0.434 \\
\hline
\end{tabular}

Keterangan: Angka yang diikuti huruf yang berbeda pada baris yang sama menunjukkan perbedaan yang signifikan pada taraf 5\%. KA: ketamine-acepromazine; KM: ketamine-medetomidine dan ZX: tiletamine/zolazepam-xylazine; IVSd: interventricular septum, diastole; LVIDd: left ventricular internal dimention, diastole; LVPWd: left ventricular posterior wall, diastole; IVSs: interventricular septum, systole; LVIDs: left ventricular internal dimention, systole; LVPWs: left ventricular posterior wall, systole 


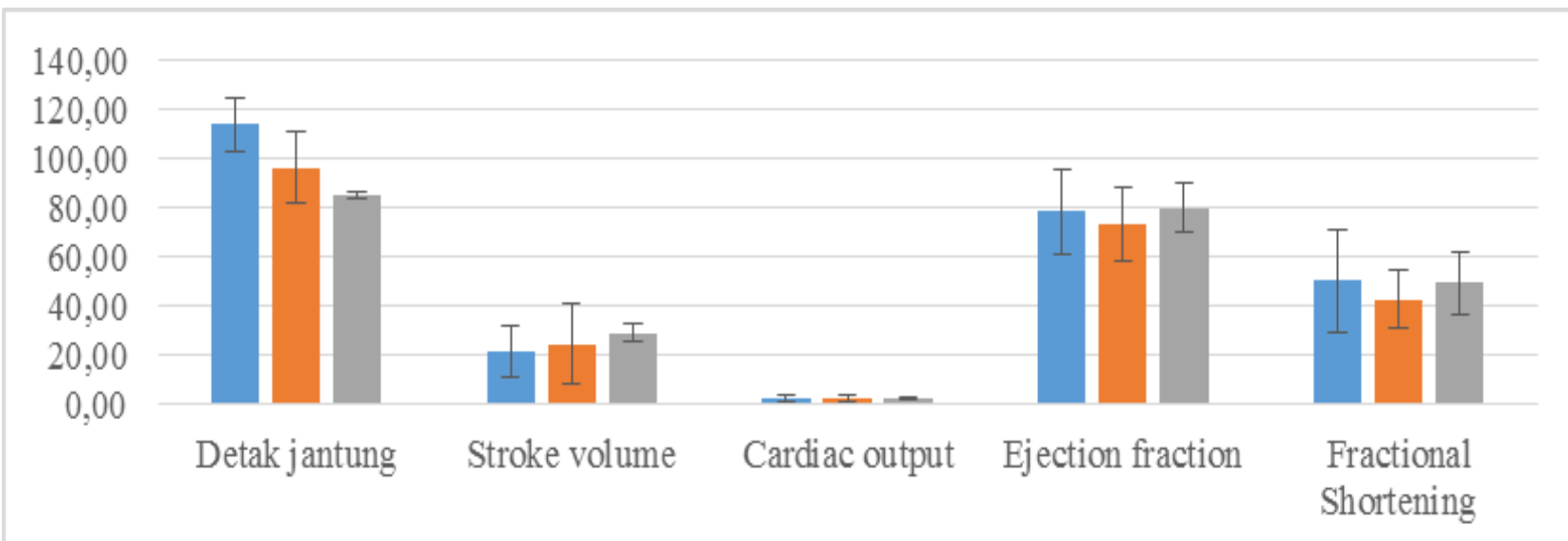

- KA $\square \mathrm{KM}=\mathrm{ZX}$

Gambar 1 Pengaruh sinergis pemberian perlakuan kombinasi anestesia umum pada babi domestik (Sus domesticus) terhadap detak jantung, stroke volume, cardiac output, ejection fraction dan fractional shortening dari pengamatan ekokardiografi. KA: ketamine-acepromazine; KM: ketamine medetomidine; tiletamine dan zolazepam-xylazine

Tabel 4 Data rata-rata \pm simpangan baku hasil perhitungan kinerja jantung babi domestik (Sus domesticus) yang diberi perlakuan 3 kelompok kombinasi anestesia umum

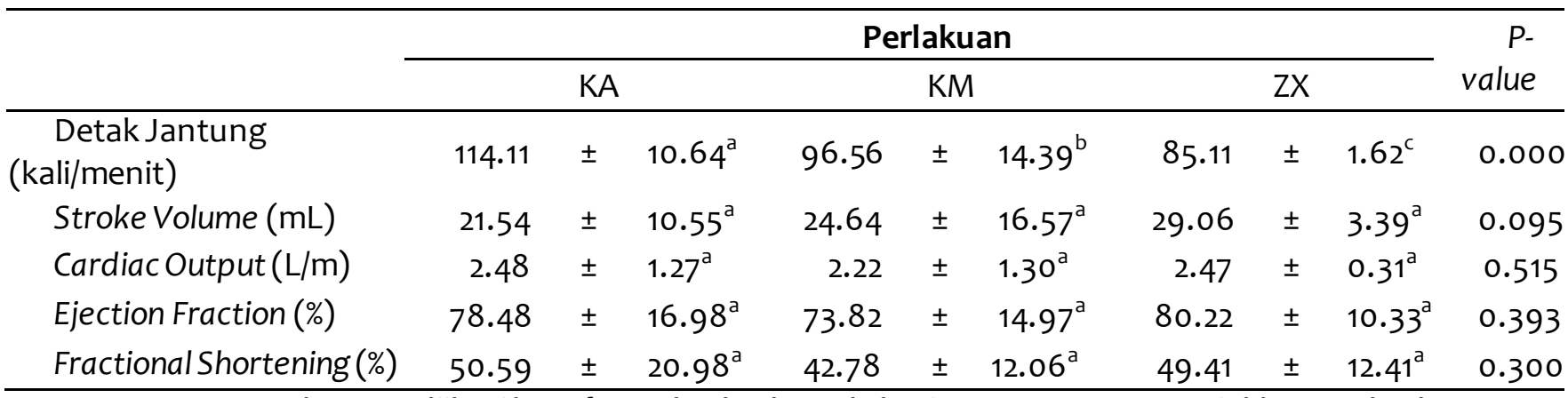

Keterangan: Angka yang diikuti hurufyang berbeda pada baris yang sama menunjukkan perbedaan yang signifikan pada taraf 5\%. KA: ketamine-acepromazine; KM: ketamine-medetomidine dan ZX: tiletamine dan zolazepam-xylazine

obat bius yang berbeda tidak memengaruhi ukuran maupun perluasan ruang jantung terutama ventrikel kiri.

Dari diagram Gambar 1 terlihat kelompok ZX memiliki fekuensi jantung paling stabil. Nilai paling tinggi pada kelompok KA terjadi akibat pengaruh kerja obat ketamine. Ketamine memiliki efek anestesia dan analgesi yang cepat.

Kerja ketamine tidak mendepres sistem organ kardiopulmonari, dan lebih banyak menjadi kardiostimulator yang artinya akan meningkatkan detak jantung pada saat obat sudah memengaruhi tubuh. Ketamine bisa meningkatkan cardiac output, heart rate, tekanan mean aortic, tekanan arteri pulmonary dan tekanan CNS (Erstad \& Patanwala, 2016; Plumb, 2018). Mekanisme kerja ketamine kemungkinan menghambat efek membran eksitatori neurotransmiter asam glutamat pada suptipe reseptor NMDA (Erstad \& Patanwala, 2016).

Ketamine merupakan obat yang sangat lipofilik dan didistribusikan dengan cepat ke dalam organorgan yang kaya vaskuler, termasuk otak, hati dan ginjal kemudian obat ini di distribusikan kembali kedalam jaringan-jaringanyang kurang vaskularisasi, bersamaan dengan metabolisme obat di hati untuk selanjutnya dibuangke urin dan empedu (Andrade, 2017). 
Dilihat dari cara kerja anestesia memang terlihat bahwa obat anestesia ketamine, acepromazine, tiletamine dan zolazepam, berpengaruh terhadap tekanan darah dan meningkatkan jumlah detak jantung (Plumb, 2018). Sementara medetomidine dan xylazine memiliki kesamaan kerja menurunkan laju detak jantung meskipun medetomidine lebih dominan cara kerjanya jika dibandingkan xylazine dalam memengaruhi kerja alpha-2 agonis (Karasu et al., 2018; Kitano et al., 2019).

Stroke volume merupakan penentu dari output jantung yang merupakan hasil perkalian stroke volume dengan laju detak jantung, dan juga penentu perhitungan ejection fraction (EF). Stroke volume sangat berkorelasi dengan fungsi jantung. Secara fisiologi, stroke volume merupakan banyaknya volume darah yang dipompa dari ventrikel kiri per detak jantung (Kenny et al., 2020). Stroke volume diukur dari selisih volume diastoldan volume sistol (Tabel 2), dari hasil uji lanjut didapatnilai $P>0.05$. Meskipun nilai rataan terlihat ada perbedaan, namun dengan pengujian statistika tidak terdapat perbedaan yang signifikan antara ketiga kelompok perlakuan tersebut.

Cardiac output yang ditunjukkan pada hasil penelitian menunjukkan bahwa kombinasi dengan agen enestesia medetomidine menunjukkan nilaidibawah rataan kombinasi kelompok lainnya. Hal ini dilihat dari kerja medetomidine menurunkan laju detak jantung yang bisa memengaruhi $\mathrm{CO}$ ikut turun (Sinclair, 2003; Plumb, 2018).

Presentase EF yang paling rendah pada kelompok KM terjadi dikarenakan mekanisme kerja medetomidine agonis alpaz adrenoreseptor baik peripheral dan central menyebabkan muskulorelaksan. Medetomidine berpengaruh terhadap kardiovaskular dan menyebabkan kontraksi otot jantung menurun (Plumb, 2018). Medetomidine menyebabkan hipotensi. Dosis obat penenang medetomidine biasanya meningkatkan tekanan darah, karena efek pada adrenoreseptor $\alpha 2$ perifer (Sinclair, 2003).

Fractional shortening (FS) adalah persentase perubahan dimensi kapasitas ventrikel kiri pada awalnya dengan kontraksi saat sistol. Persentase FS sering kali digunakan untuk mengukur dan menilai disfungsi ventrikel kiri, namun belum secara sistematik digunakan untukuji kinerja ventrikel kanan (Srinivasan et al., 2017). Data hasil FS yang yang didapat menunjukkan bahwa agen anestesia medetomidine meskipun dikominasikan dengan obat lain tetap paling mendominasi aksi dalam tubuh (Plumb, 2018).

Hasil uji lanjutan dari nilai FS pada ketiga perlakuan kombinasi obatbius nunjukkan nilai $P>0.05$ yang artinya tidak ada perbedaan yang signifikan nilai FS dari berbagai kombinasi anestesia. Menurut penyataan Sinclair (2003), efek kardiovaskular negatif spesifik yang dihasilkan agonis $\alpha 2$ lainnya seperti bradikardia, bradiaritmia, penurunan curah jantung, hipertensi \pm hipotensi, juga diproduksi dengan medetomidine, sehingga perlu tindakan pencegahan ketika digunakan dan mengharuskan pemilihan pasien yang berusia muda atau dewasa yang sehat.

Hasil analisis stroke volume, cardiac output, ejection fraction, dan fractional shortening tidak berbeda nyata pada ketiga kelompok perlakuan. Hal ini menunjukkan bahwa ketiga kombinasi anestesia yang digunakan tidak memengaruhi stroke volume, cardiac output, ejection fraction, dan fractional shortening.

Pemberian kombinasi anestesia ketamineacepromazine; ketamine-medetomidine dan tiletamine dan zolazepam-xylazine, menunjukkan perbedaan pada nilai laju detak jantung, dengan perbedaan nilai yang signifikan antara ketiga perlakuan, namun masih dalam batas normal fisiologis babi domestik (Sus domesticus). Pemberian ketiga kombinasi anestesia ini tidak memengaruhi nilai cardiac output, stroke volume, ejection fraction dan fractional shortening jantung pada gambaran ekokardiografi. Kombinasi anestesia perinjeksi tiletamine dan zolazepam-xylazine paling baik diaplikasikan untuk bedah jantung babi karena dengan kombinasi anestesia ini menghasilkan kecepatan frekuensi detak jantung stabil rendah dibandingkan dengan kombinasi anestesia kelompok lainnya namun masih menunjukan nilai SV, CO, EF dan FS tinggi. Sebaliknya kombinasi ketamine-acepromazine dan ketaminemedetomidine kurang sesuai digunakan untuk penelitian bedah jantung karena selain detak jantung yang dihasilkan menjadi meningkat, parameter stroke volume, cardiac output, ejection fraction dan fractional shortening tidak sebaik kombinasi tiletamine dan zolazepam-xylazine.

\section{UCAPAN TERIMA KASIH}

Ucapan terima kasih penulis sampaikan kepada PT MUM yang telah memfasilitasi peralatan USG di RSHP FKH IPB sehingga dapat dilakukan Penelitian ini. Ucapan terimakasih juga kami sampaikan untuk pembimbing, staffkolega dokter hewan dan pegawai yang telah terlibat dalam penulisan naskah ini. 
"Penulis menyatakan tidak ada konflik kepentingan dengan pihak-pihak yang terkait dalam penelitian ini".

\section{DAFTAR PUSTAKA}

[FASS] The Federation of Animal Science Societes. 2010. Guide for the Care and Use of Agricultural Animals in Research and Teaching. $3^{\text {rd }}$ ed. American Dairy Science Association ${ }^{\circledR}$. ISBN (13): 978-1884706-11-0.

[NRC] National Research Council. 2011. Guide for The Care and Use of Laboratory Animals. $8^{\text {th }}$ ed. The National Academies Press. Washington DC (US).

Akata T. 2007. General anesthetics and vascular smoothmuscle: Directactions of generalanesthetics on cellular mechanisms regulating vascular tone (Review). Anesthesiology 106: 365-391.

Andrade C. 2017. Ketamine for depression, 1: clinical summary of issues related to efficacy, adverse effects, and mechanism of action. The Journal of Clinical Psychiatry 78(4): 415-419.

Boon JA. 2011. Veterinary Echocardiography. $2^{\text {nd }}$ ed. Blackwell Scientific. United Kingdom.

Erstad BL, Patanwala AE. 2016. Ketamine for analgosedation in critically ill patients. Journal of Critical Care 35: 145-149.

Flecknell P. 2009. Laboratory Animal Anaesthesia. $3^{\text {rd }}$ ed. Elsevier. Newcastle (UK).

Fontes-Sousa APN, Brás-Silva C, Moura C, Areías JS, Leíte-Moreíra. 2006. M-mode and Doppler echocardiographic reference values for male New Zealand white rabbits. American Journal of Veterinary Research 67 (10): 1725- 729.

Gunanti, Siswandi R, Soehartono RH, Ulum MF, Sudisma IGN, 2011. Pembiusan babi model laparoskopi untuk manusia dengan zoletyl, ketamine dan xylazine. Jurnal Veteriner 12 (4): 247-253.

Karasu A, Altug NURI, Aslan LOGMAN, Bakir B, Yuksek N. 2018. Evaluation of the anesthetic effects of xylazine-ketamine, xylazine-tiletaminezolazepam and tiletamine-zolazepam using clinical and laboratory parameters in rabbits. Medycyna Weterynaryjna 74(10).

Kenny, JÉS, Barjaktarevic I, Eibl AM, Parrotta M, Long BF, Eibl JK, Michard F. 2020. A carotid doppler patch accurately tracks stroke volume changes during a preload-modifying maneuver in healthy volunteers. Critical Care Explorations 2(1): e0072.
Kitano T, Kobayashi T, Yamaguchi S, Otsuguro KI. 2019. The a2A-adrenoceptor subtype plays a key role in the analgesic and sedative effects of xylazine. Journal of Veterinary Pharmacology and Therapeutics 42(2): 243-247.

Kolh P, Lambermont B, Ghuysen A, Tchana-Sato V, Dogné, JM, D'Orio $V$, Limet $R$, Gerrad $P$, Larbuisson R. 2004. Comparison of the effects of propofol and pentobarbital on left ventricular adaptation to an increased afterload. Journal of Cardiovascular Pharmacology 44(3): 294-301.

Lee MY, Lee SH, Lee SG, Park SH, Lee CY, Kim KH, Han HJ et al., 2007. Comparative analysis of heart functions in micropigs and conventional pigs using echocardiography and radiography. Journal of Veterinary Science 8(1): 7-14.

Liu C, Eggen MD, Swingen CM, laizzo PA, He B. 2012. Noninvasive mapping of transmural potentials during activation in swine hearts from body surface electrocardiograms. IEEE Transactions on Medical Imaging 31(9): 1777-1785.

Mohamed AA, Arifi AA, Omran A. 2010. The basic of echocardiography. J Saudi Heart Assoc 22(2): 7176. Doi: 10.1016/j.jsha.2010.02.011.

Noviana D, Aliambar SH, Ulum MF, Siswandi R, Widyananta BJ, Gunanti, Soehartono RH, Soesatyoratih R, Zaenab S. 2018. Diagnosis Ultrasonografi pada Hewan Kecil. Edisi ke-2. IPB Press. Bogor. ISBN: 978-602-440-288-4.

Penninck D, Andre'd'Anjou M. 2015. Atlas of Small Animal Ultrasonography. $2^{\text {nd }}$ ed. Wiley Blackwell. lowa (USA). ISBN-13: 978-1-1183-5998-3.

Plumb DC. 2018. Plumb's Veterinary Drug Han dbook: Pocket. John Wiley \& Sons.

Pop M, Ghugre NR, Ramanan V, Morikawa L, Stanisz G, Dick AJ, Wright GA. 2013. Quantification of $\mathrm{fi}$ brosis in infarcted swine hearts by ex vivo late gadolinium-enhancement and diffusion-weighted MRI methods. Physics in Medicine \& Biology 58(15): 5009.

Sakaguchi $M$, Nishimura R, Sasaki N, Ishiguro T, Tamura H, Takeuchi A. 1995. Chemical restraint by medetomidine-ketamine and its cardiopulmonary effects in pigs. Journal of Veterinary Medicine Series A 42(1-10): 293-299.

Sinclair MD. 2003. A review of the physiological effects of a2-agonists related to the clinical use of medetomidine in small animal practice. The Canadian Veterinary Journal 44(11): 885.

Smith AC, Swindle MM. 2006. Prepatation of swine for the laboratory. ILAR Journal 47(4): 358-363. 
30 | Fitri et al.

Srinivasan A, Kim J, Khalique O, Geevarghese A, Rusli M, Shah T, Devereux, RB et al. 2017. Echocardiographic linear fractional shortening for quantification of right ventricular systolic function-A cardiac magnetic resonance validation

Swindle MM, Smith AC, Laber KL, Goodrich JA, Bingel SA. 2003. Biology and medicine of swine.
Laboratory Animal Medicine and Management. Ithaca, New York: International Veterinary Information Service.

Yitnosumarto S. 1991. Percobaan Perancangan, Analisis, dan Interpretasi. Jakarta: PT. Gramedia Pustaka Utama. 